\title{
Stem Cells in Functional Bladder Engineering
}

\author{
Jakub Smolar ${ }^{a}$ Souzan Salemi ${ }^{a} \quad$ Maya Horst $^{b} \quad$ Tullio Sulser $^{a}$ Daniel Eberli ${ }^{a}$ \\ ${ }^{a}$ Laboratory for Tissue Engineering and Stem Cell Therapy, Department of Urology, University Hospital Zurich, Zurich, Switzerland; \\ ${ }^{b}$ Division of Pediatric Urology, Department of Pediatric Surgery, University Children's Hospital, Zurich, Switzerland
}

\section{Keywords}

Stem cells $\cdot$ Bladder wall $\cdot$ Tissue engineering

\section{Summary}

Conditions impairing bladder function in children and adults, such as myelomeningocele, posterior urethral valves, bladder exstrophy or spinal cord injury, often need urinary diversion or augmentation cystoplasty as when untreated they may cause severe bladder dysfunction and kidney failure. Currently, the gold standard therapy of end-stage bladder disease refractory to conservative management is enterocystoplasty, a surgical enlargement of the bladder with intestinal tissue. Despite providing functional improvement, enterocystoplasty is associated with significant long-term complications, such as recurrent urinary tract infections, metabolic abnormalities, stone formation, and malignancies. Therefore, there is a strong clinical need for alternative therapies for these reconstructive procedures, of which stem cell-based tissue engineering (TE) is considered to be the most promising future strategy. This review is focused on the recent progress in bladder stem cell research and therapy and the challenges that remain for the development of a functional bladder wall.

(c) 2016 S. Karger GmbH, Freiburg

\section{Introduction}

To overcome pathological conditions, such as neuropathic bladder, congenital disorders and malignancies, an improvement of bladder regeneration and the replacement of urinary bladder tissue with functional equivalents remain the major challenges in the field of bladder tissue engineering (TE). Upon failure of conserva- tive treatments, these conditions require reconstructive procedures such as augmentation cystoplasty, e.g. the use of gastrointestinal tissue as bladder replacement [1-3]. However, due to unwanted side effects associated with this treatment, such as increased mucus production, stone formation, recurrent urinary tract infections and malignancies, alternative treatments utilizing bioengineered scaffolds, stem and/or primary cells and supportive factors have been proposed [4].

In the last two decades many different natural (amniotic membrane [5], bladder acellular matrix [6], collagen [7], silk [8, 9]) and synthetic poly lactic-co-glycolic acid (PLGA), polyurethane [10], poly-carbonate-urethane-urea [11]) matrices have already found their application in preclinical and clinical bladder TE [12, 13]. In recent years the use of (multi-)layered hybrid scaffolds has been established, as such combinatorial approaches often result in a more specific, customized microenvironment for each cellular layer, an improved regeneration, and better biomechanical properties of the construct [14-16].

To further enhance the regeneration efficiency and improve the scaffold functionality and integration into the surrounding tissue, the scaffolds are seeded with various cells. However, the use of primary cells is often limited by their short life span, and they cannot be isolated from diseased tissue, for example urothelial progenitors from bladder cancer patients or smooth muscle cells (SMCs) from neuropathic bladders $[17,18]$. Based on their ability for multilineage differentiation, plasticity, migration and self-renewal, stem cells are being considered suitable candidates to further improve tissue regeneration and to facilitate faster incorporation of transplanted bioscaffolds into the native tissue without the primary cell drawbacks $[19,20]$. Furthermore, stem cell secretome may improve vascularization [21], cellular coordination, and survival of resident and transplanted cells in the regenerating tissue [22]. Moreover, stem cells exhibit immunomodulatory abilities affecting the length and strength of the inflammatory response, tissue remodeling, and thus the overall structure of the local extracellular matrix (ECM) and surrounding microenvironment [23, 24]. Fur-

\section{KARGER}

(๑) 2016 S. Karger GmbH, Freiburg

Fax +497614520714 
thermore, adipose tissue-derived stem cells (ADSCs) have been found to secrete lymphangiogenic factors and promote the formation of the lymphatic system [25], exhibiting an even more striking effect on the immune system.

To further improve cell survival, proliferation and motility, tissue vascularization and innervation and to tailor the bioengineered scaffold microenvironment to the needs of local and implanted cells, a variety scaffold modifications can be performed [26, 27]. Beside structural alterations, such changes in porosity [28] the use of VEGF, bFGF $[29,30]$, and other growth factors has been a common practice. Additionally, recent novel tools and techniques added to the expanding list of possibilities, with the most promising ones coming from the field of nanotechnology. Nanostructured co-polymers [10], nano-sized ECM coatings on synthetic polymers [31], and combinations of growth factor-laden synthetic nanoparticles with bladder acellular matrix for their directed delivery [29] are just a few examples.

\section{Bladder Anatomy}

Urinary bladder is a complex, hollow organ that is composed of several cell and ECM layers the interaction of which provides for its proper function, e.g. acting as an efficient barrier against urine as well as its accumulation, storage, and controlled release [32]. This process is being coordinated by the afferent and efferent neuronal pathways that transfer the sensory signals towards the central nervous system and feedback the response back to the bladder tissue, causing coordinated detrusor muscle contraction and voiding $[33,34]$.

The bladder wall is organized into histologically distinct compartments. The mucosa encompasses several layers of transitional uroepithelium and is separated from the submucosa by the basal lamina. On top of the highly vascularized and innervated lamina propria lies the main functional bladder part consisting of three smooth muscle layers that provide for coordinated micturition. The urinary bladder is covered by adventitia, a connective tissue layer facilitating protection, vascularization and innervation to the bladder wall [35].

It is its unique anatomic structure resulting in special requirements on the biomechanical properties of an adequate substitute which represents a major difficulty in the development of such a functional bioengineered bladder wall equivalent [36].

\section{Urothelium}

Two major critical urothelial functions are a resilient and effective barrier against urine and a sensory network formation that, via its paracrine signaling, stimulates the afferent neurons that are responsible for the direct control of the bladder filling [35, 37]. The urothelium has a multilayered structure with fully differentiated, binuclear umbrella cells covered with a protective glycosaminoglycan layer on the bladder luminal site $[38,39]$. The underlying intermediate cells show limited proliferative potential while the basal urothelium is able to generate large cell numbers in vitro [40]. In contrast to other epithelial tissues such as the gut, the urothelial turnover rate is rather low and the shift to a highly proliferative state happens only in cases of epithelial injury, cancer, or urinary tract infection [41].

Several stem cell sources have been discussed in the literature as a possible urothelial replacement after injury. Almost a decade ago, Anumanthan et al. [42] reported a directed differentiation of bone marrow stem cells to urothelial cells utilizing embryonic rat bladders that have been stripped off urothelium and seeded with mesenchymal stem cells. The constructs were implanted into the renal subcapsular space of athymic mice for 42 days, resulting in a multilayered, urothelium-like structure formation. In a newer study, Zhang et al. [43] were able to increasingly differentiate ADSCs into urotheliallike cells by directly co-culturing them with the SV-HUC-1 human urothelial cancer cell line in a time-dependent manner.

Another viable source of multipotential cells suited for genitourinary therapeutic approach may be the urine-derived stem cells (UDSCs). Bharadwaj et al. [44] obtained a small UDSC population from fresh urine samples of healthy patients of various ages and showed their ability to expand to a large cell population, while proving that the UDSCs can be differentiated into urothelium and other cell types efficiently simply by changing the culture medium composition. While the source of these cells is unknown, it has been proposed that they are of renal origin, as they express the kidney-related markers PAX8, NR3C2 and L1CAM $[45,46]$.

However, due to very rapid natural urothelial regeneration after injury and fast urothelial ingrowth onto the transplanted luminal biomaterial surface, strategies providing suitable biomaterial mimicking the basilar membrane without urothelial cell coverage may well be used in regenerative medicine therapies for urothelial repair $[15,47]$.

\section{Lamina propria}

Beside afferent and efferent nerve endings, the submucosal layer of the bladder lamina propria (LP) contains fibroblasts, adipocytes, and interstitial cells of unknown origin and function [48, 49]. LP is rich on type III collagen, elastin, laminin, and fibronectin [50] as well as a variety of growth factors such as VEGF, bFGF, EGF, and PDGF [51] that are crucial for the urothelial and SMC survival and proliferation [52]. Moreover, an increasing amount of evidence shows the importance of this ECM-rich, highly vascularized and innervated layer in the crosstalk between the urothelium and the detrusor muscle [48]. However, a little attention has been given to the LP in the field of bladder TE so far as better understanding is required to fittingly use this compartment to facilitate bladder regeneration.

\section{Detrusor Muscle}

Detrusor muscle is the major functional part of the bladder. This muscle layer is controlled by autonomic efferent sympathetic 
and parasympathetic neurons acting as the major excitatory mechanism of bladder SMCs and allowing for coordinated storage and emptying of urine [53].

Bladder SMCs can be easily isolated by explant and enzyme treatment methods from human and rodent bladder [54, 55]. However, several issues currently limit their applicability. Beside their restricted proliferation ability and the loss of contractile phenotype during in vitro culture and expansion [56], there are many obstacles associated with utilizing patients' own SMCs, such as sample size limitation and pathological changes $[18,57]$. Thus, to overcome these constraints, adult [58], embryonic (ESCs) [59] and induced pluripotent stem cells (iPSCs) [60] have been considered potential candidates for detrusor muscle bioengineering.

The ability of adult stem cells to differentiate and self-renewal makes them a suitable source for bladder TE. Many adult stem cell types have been utilized for bladder SMC bioengineering, such as ADSCs [61], UDSCs [62-64], endometrium [65], menstrual blood bone marrow-derived stem cells (bMSCs) [66], and dental pulp stem cells (DPSCs) $[67,68]$.

ADSCs are one of the most promising candidate cells for bladder engineering mainly due to their high abundance in and comparatively simple isolation from patients [58]. Efficient myogenic ADSC differentiation using induction media MCDB131 supplemented with heparin $[61,69]$ or addition of growth factors, such as TGF- $\beta 1$ and BMP4 were reported by several groups [70]. Improved bladder architecture was observed in small animal models upon ADSC injection [71] or in combination with an acellular scaffold [72]. Furthermore, a recent study utilizing ADSCs in combination with a bladder acellular matrix graft in a rat model resulted in an enhanced detrusor muscle, neuronal regeneration, and improved bladder capacity [73].

Recently, human UDSCs isolated from voiding urine were proposed as a good source for urological tissue bioengineering [6264]. The mesenchymal-like UDSCs [44] have demonstrated their ability to differentiate to SMCs upon myogenic differentiation [62] with a similar contractile phenotype [64]. After differentiation, the SMC-like UDSCs were seeded on bacterial cellulose polymer and implanted subcutaneously into nude mice where they formed multiple urothelial and SMC layers [63]. Furthermore, human UDSCs seeded on heparin-bFGF-enriched scaffold exhibited organized smooth muscle tissue and urothelial formation, resulting in an enhanced biocompatibility, increased bladder capacity, and compliance in a partial cystectomy rat model [74]. The effortless collection, low-cost, safety and differentiation capacity of UDSCs to SMCs make them a good stem cell source for detrusor muscle engineering $[63,75]$.

Current in vitro studies suggest endometrium [65] and menstrual blood [66] as stem cell sources expressing mesenchymal lineage-specific markers [76]. However, at this stage the results are inadequate and require further research and confirmation in animal models.

bMSCs are an alternate, well established cell source for detrusor bioengineering. It was shown that bMSCs exhibit similar features and phenotype to bladder SMCs in vitro $[77,78]$. Moreover,
Sharma et al. [79] demonstrated an improved bladder reconstitution, an increased SMC marker expression, and a higher number of smooth muscle bundles when seeding bMSCs on elastomeric scaffold compared to human bladder SMCs and to unseeded control animals in a nude rat bladder augmentation model after 10 weeks. In a recent study by Coutu et al. [80], decellularized bladder acellular matrix (BAM) was seeded with rat bMSCs and transplanted into rat bladder after partial cystectomy. MSC-seeded BAM exhibited increased muscle regeneration and a significantly improved bladder capacity and compliance compared to BAM alone, almost reaching healthy rat bladder values.

In another study performed by Chung et al. [81] bMSCs seeded on SIS showed rapid cellular regeneration of bladder constituents morphologically and genetically. A similar study utilizing a bMSCseeded small intestinal submucosa (SIS) in a canine hemicystectomy and bladder augmentation model showed similar cell proliferation, morphology, and contractility as bladder SMCs in vitro and resulted in successful bladder regeneration in vivo [82].

In a similar approach umbilical cord blood-derived MSCs were seeded on BAM used as a graft for bladder defect reconstruction in a canine model. Their application resulted in a multilayered urothelium and a well-developed smooth muscle layer compared to the unseeded group after 12 weeks of in vivo regeneration, confirming their excellent regenerative capacity [83].

Lastly, in their study Song et al. [67] differentiated mesenchymallike DPSCs arising from their perivascular niche into SMC-like cells in vitro using a combination of condition media for bladder SMCs and TGF- $\beta 1$. Compared to other MSCs derived from bone marrow, adipose tissue or peripheral blood, DPSCs have a striking advantage due to their availability with least invasive procedures without any ethical concerns. Despite the promising results, more work is required to investigate function of SMC-like DPSCs in vivo.

The pluripotent ESCs are isolated from the inner cell mass of embryo's blastocyst and can form the cells of all three primary germ layers: ectoderm, endoderm and mesoderm. Thus they are able to expand into the majority of cell types within the body. ESCs are a valuable cell source to study SMC differentiation and to test medicinal therapeutic agents. Blank et al. $[84,85]$ reported the first in vitro system, in which the mouse embryonal carcinoma P19 cells were induced to become SMCs under retinoic acid treatment, expressing SMC gene markers. A similar approach was used to differentiate human ESCs into SMCs in the presence of retinoic acids [86]. Another efficient method to differentiate SMCs from human ESCs was described by Xie et al. [87] who showed SMC lineage marker upregulation and active contraction of SMC-like cells in the presence of carbachol, a muscarinic agonist.

Direct ESC use for bladder regeneration was shown by Lakshmanan et al. [88] who generated viable in vitro grafts by seeding human ESCs in co-culture with bladder SMCs and urothelium on SIS. In a later study, the same construct was utilized to augment a previously injured rat bladder, resulting in an improved regeneration of the ESC-seeded graft compared to unseeded SIS [89]. However, despite these remarkable results the use of human ESCs for clinical treatments remains ethically controversial. 
iPSCs can offer a theoretically unlimited number of differentiated cells for use in TE and autologous cell therapies; however, their efficacy and safety is still under investigation. Human smooth muscle iPSCs have been generated in vitro with different efficiencies using several differentiation protocols directing the cells towards the contractile [14] or synthetic [90] SMC phenotype [60, 91]. Depending on the research question asked, an appropriate protocol should be selected, and the in vitro differentiation efficiency and in vivo safety should be tested.

\section{Vascularization}

During the first days after in vivo transplantation, before the development of a functional vascular plexus, cell survival in a bioengineered bladder wall equivalent is solely dependent on oxygen and nutrient diffusion from the surrounding tissue. Resultant anoxic microenvironment combined with the lack of nutrients usually causes cell death, inflammation, and necrosis in the transplanted substitute, considerably impairing tissue regeneration [4]. To minimize these adverse effects, rapid neo-vascularization of the bioengineered scaffold is crucial.

The standard procedures in TE to facilitate angiogenesis into a bioengineered scaffold utilize VEGF and bFGF [4, 29, 30]. Other growth factors, such as angiopoietin 1 and 2, PDGF and TGF- $\beta$ have also been considered due to their direct and indirect pro-angiogenic effects in vivo [92]. However, clinical growth hormone therapies are being used only in rare cases as their directed regulation is difficult. Therefore, further TE approaches to improve cell survival after transplantation, e.g. the use of oxygen-releasing biomaterials [93] and scaffold modifications using in vivo light activated adhesive peptides to enhance vascularization [94], have been developed. Such biomaterial-based methods can be combined with primary endothelial cells (ECs) to form pre-vascularized networks to facilitate rapid blood supply in the transplanted tissues $[95,96]$.

Beside primary ECs, various stem cells such as ADSCs [97] and MSCs [98] have been found to potently facilitate neo-vascularization due to their considerable pro-angiogenic secretome $[22,99]$. Furthermore, based on their close resemblance to pericytes, ADSCs and MSCs may provide for additional pro-angiogenic effect by stabilizing newly formed blood vessels [100, 101]. Such an effect has been described by Grainger et al. [102] who showed that the combination of primary ECs with ADSCs and MSCs resulted in a formation of more mature capillaries and less extravascular leakage compared to human lung fibroblasts. Also the EC-ADSC and ECMSC constructs exhibited more mature pericyte markers. Moreover, combinatory approaches such as genetic modification of MSCs to overexpress WNT-5 [103] or the co-administration of controlreleased bFGF along with ADSCs [104] may lead to a further improved bladder neo-vascularization.

Despite its importance in the development of functional bladder tissue, vascularization has not been a major focus in bladder TE so far as many fundamental issues such as the generation of functional bladder smooth muscle still limit its application to a full potential.

\section{Innervation}

To ensure smooth muscle long-term functionality and survival, a complex neuronal network has to be established during tissue regeneration and scaffold engraftment. Such networks require proper afferent and efferent neuronal endings to connect with the appropriate cellular compartments in the regenerating bladder wall and ensure its correct function [105]. Despite its major importance for the development of functional bladder tissue, stable re-innervation has not been a primary target of bladder TE yet as many crucial parts in the functional upstream are still unknown. Nevertheless, despite the lack of understanding, we outline a hypothetical approach for functional bladder innervation based on recent neurological TE research.

The simplest yet highly efficient approach in neuronal TE involves NGF [33] embedded in synthetic or natural scaffolds [106, 107]. Such constructs provide spatial and signaling ques allowing neuronal guidance from the spinal cord to the regenerating bladder tissue. Other growth factors such as neurotrophin-3, ciliary neurotrophic factor, VEGF, and IGF-1 [108] may be used to further facilitate peripheral nerve regeneration. However, such treatments have their spatial and temporal limitations and might lead to an uncontrolled localized neuronal outgrowth and random formation of neuronal pathways in the tissue. An improved neuronal guidance connecting the dorsal root ganglia with the regenerating bladder wall could further be achieved using electroactive tissue scaffolds [109]. In addition to neuronal outgrowth and guidance, electroactive polyurethane was found to significantly enhance Schwann cells' neurotrophin secretion and myelin gene expression, showing great potential to stabilize newly developing peripheral neuronal pathways [110]. More complex approaches, such as the development of composite silk fibroin-based nerve guidance conduits [111] or a combination of electrospun NGF-releasing poly-Llactic acid microfibers with iron oxide nanoparticles [112], may result in an enhanced, more directed neuronal guidance over prolonged distances.

Stem cell-based in vitro generation of peripheral neurons and Schwann cells, their growth on a tailored scaffold, and subsequent transplantation onto the bladder wall may be a viable approach to ensure a comprehensive bladder innervation. A subsequent, longterm electromagnetic stimulation is likely to be needed thereafter to ensure the smooth muscle and neuronal survival and prime the neurons to propagate into the specific bladder tissues [113, 114].

To obtain an adequate number of Schwann cells, various stem cell types [115] including ADSCs [116], bMSCs- and DPSCs [117, 118] can be isolated, expanded and differentiated using conditioned media. Additionally, neuronal ADSC differentiation can be achieved by simply applying electric current combined with copper electrodes [119]. In addition to their differentiation potential, ADSCs show indirect, most probably paracrine neurotropic regenerative abilities [120].

It is likely that for the development of a functional neuronal network a combined approach is needed that utilizes synergistic techniques from many different TE fields. 


\section{Clinical Bladder Tissue Engineering}

Bladder TE has seen its first successful clinical implementation in the late 1950s [121]. Two major approaches have been developed over the years so far, the first of which utilizes the use of natural or synthetic scaffolds alone with the idea to support native cell ingrowth and thus the regeneration of the bioengineered tissue/ scaffold, while the second approach includes combinations of autologous cells and biomaterials. A variety of natural and synthetic materials have been investigated and clinically applied by several research groups since.

In early studies, the use of bladder-shaped plastic molds as substitutes for bladder reconstruction has been reported by several researchers. These new bladders consisted mainly of fibrotic tissue leading to various complications without functional tissue regeneration [121-124].

A more sophisticated approach using gelatin sponge for bladder reconstruction in bladder cancer patients was performed by Tsuji et al. [125]. Due to its structural composition the gelatin sponge provided more suitable microenvironment for tissue growth and improved degradability over time. Despite an early improvement in bladder capacity shortly after transplantation, patients showed severe urinary incontinence, urine leakage, and other complications thereafter $[122,125]$. In a subsequent clinical trial, gelatin sponges were pretreated with nobecutane or rezifilm before their use as augments for bladder enlargement. These constructs showed increased bladder capacity, complete epithelial covering, excellent smooth muscle regeneration, and no inflammatory reaction. According to the authors, the patients did not show any urinary complications [126]. However, the fact that gelatin sponge has not been used since then in further clinical trials of bladder augmentation indicates skepticism about the reliability of the presented results. These doubts have been confirmed by Taguchi et al. [127] who showed that the gelatin sponge disintegrated into small pieces in vivo. In combination with nobecutane it formed synthetic resinlike structures and did not degrade, forming calculi in the tissue.

Another partial success of human bladder augmentation was reported using formalin-preserved dog bladders as temporal scaffolds for tissue growth in patients after sub-total or radical cystectomy. Although a pseudo-bladder developed in relatively short time, it showed decreasing capacity over time, and patients frequently suffered from urinary incontinence, vesicoureteral reflux, and ureteral orifices [128].

The first clinical study utilizing patients' own autologous cells in combination with collagen alone or a collagen-PGA hybrid constructs was published in 2006. The bladder substitutes were seeded in vitro with urothelial and smooth muscle cells and implanted in young patients with myelomeningocele and end-stage bladder disease [129]. After a mean follow-up of 46 months, the collagen-PGA composite resulted in a significantly improved bladder regeneration compared to collagen scaffold alone. An additional omental wrap enhanced the graft vascularization, further improving the transplanted cell survival and scaffold engraftment. Morphological analysis of the scaffold biopsies showed proper architecture of the recon- structed bladder wall. However, only two patients showed increased bladder compliance and capacities and longer dry periods over time. The majority of treated patients lacked an improvement in bladder compliance and capacity and showed the development of fibrous tissue in their transplanted bladder walls. Although this study demonstrated the feasibility and safety of the transplantation technique, it requires further research to achieve a functional bladder equivalent.

While several pre-clinical studies demonstrated a possible use of stem cells in rodent models, an effective and efficient use of TE in bladder reconstruction in patients suffering from urinary bladder disorders requires mastering of proper stem cell harvesting, culturing, differentiation, and expansion as well as designing functional scaffold modifications and microenvironment tailoring to the specific stem cell needs.

\section{Conclusion}

In the last two decades, the field of bladder TE underwent a substantial evolutional step away from simply mixing cells, biomaterial, and supportive factors to more sophisticated approaches, in the attempt to copy nature's perfection. However, despite the ongoing research an improvement in bladder functionality has not yet been achieved.

Although therapeutic stem cell use certainly is a step in the right direction, as it helps to mitigate many TE limitations, the lack of fully understanding stem cell biology is confining their applicability in this field. Furthermore, for successful stem cell use in functional bladder bioengineering, it is crucial to achieve natural crosstalk between the transplanted stem cells and the scaffold, the host immune system and the existing bladder microenvironment, a full comprehension of which is still missing.

Besides, stem cell application in bladder TE has been limited to the use of autologous cells as well as their isolation, differentiation, combination with natural or synthetic carriers, and therapeutic transplantation into the host organism. More natural approaches, such as the stimulation of resident stem and progenitor cells, supporting natural healing processes in damaged bladder tissue and modifying diseased bladder microenvironment have not yet been sufficiently investigated so far.

Due to its complexity, functional bladder TE requires an out-ofthe-box thinking and a multidisciplinary approach for its success. Its anatomically complex, multilayered structure needs a multifactorial microenvironment that has to be created to provide for each specific cell type used in its redevelopment. Clearly, more research is necessary to fully understand the possibilities and verify the optimal use of transplanted and residential stem cells for functional bladder bioengineering.

\section{Disclosure Statement}

None of the authors of this publication have a financial or personal relationship with other people or organizations that could inappropriately influence or bias the content of the paper. 


\section{References}

1 Rigaud J, Le Normand L: Augmentation enterocystoplasty (in French). Ann Urol (Paris) 2004;38:298-310.

$\checkmark 2$ Kropp BP: Small-intestinal submucosa for bladder augmentation: a review of preclinical studies. World J Urol 1998;16:262-267.

3 Wang Y, Liao L: Histologic and functional outcomes of small intestine submucosa-regenerated bladder tissue. BMC Urol 2014;10-15.

4 Horst M, Madduri S, Gobet R, Sulser T, Milleret V, Hall H, Atala A, Eberli D: Engineering functional bladder tissues. J Tissue Eng Regen Med 2013;7:515-522.

5 Adamowicz J, Pokrywczyńska M, Tworkiewicz J, Kowalczyk T, van Breda SV., Tyloch D, Kloskowski T, Bodnar M, Skopinska-Wisniewska J, Marszałek A, Frontczak-Baniewicz M, Kowalewski T A, Drewa T: New amniotic membrane based biocomposite for future application in reconstructive urology. PLoS One 2016; 11:e0146012.

6 Huang JW, Xu YM, Li ZB, Murphy SV., Zhao W, Liu QQ, Zhu WD, Fu Q, Zhang YP, Song LJ: Tissue performance of bladder following stretched electrospun silk fibroin matrix and bladder acellular matrix implantation in a rabbit model. J Biomed Mater Res Part A 2016;104:9-16.

7 Roelofs LAJ, Kortmann BBM, Oosterwijk E, Eggink AJ, Tiemessen DM, Crevels AJ, Wijnen RMH, Daamen WF, Van Kuppevelt TH, Geutjes PJ, Feitz WFJ: Tissue engineering of diseased bladder using a collagen scaffold in a bladder exstrophy model. BJU Int 2014;114: 447-457.

8 Mauney JR, Cannon GM, Lovett ML, Gong EM, Di Vizio D, Gomez P, Kaplan DL, Adam RM, Estrada CR: Evaluation of gel spun silk-based biomaterials in a murine model of bladder augmentation. Biomaterials 2011;32:808-818.

9 Sack BS, Mauney JR, Estrada CR: Silk fibroin scaffolds for urologic tissue engineering. Curr Urol Rep 2016;17: 16.

10 Yao C, Hedrick M, Pareek G, Renzulli J, Haleblian G, Webster TJ: Nanostructured polyurethane-poly-lacticco-glycolic acid scaffolds increase bladder tissue regeneration: an in vivo study. Int J Nanomed 2013;8:32853296.

11 Sivaraman S: Investigating Polymer Based Scaffolds for Urinary Bladder Tissue Engineering 2015. All Dissertations. Paper 1509. http://tigerprints.clemson.edu/all dissertations/1509 (last accessed July 26, 2016).

12 Kosinski C, Stange DE, Xu C, Chan AS, Ho C, Yuen ST, Mifflin RC, Powell DW, Clevers H, Leung SY, Chen X: Indian hedgehog regulates intestinal stem cell fate through epithelial-mesenchymal interactions during development. Gastroenterology 2010;139:893-903.

13 Pokrywczynska M, Adamowicz J, Sharma AK, Drewa T: Human urinary bladder regeneration through tissue engineering - an analysis of 131 clinical cases. Exp Biol Med 2014;239:264-271.

14 Franck D, Gil ES, Adam RM, Kaplan DL, Chung YG, Estrada Jr. CR, Mauney JR: Evaluation of silk biomaterials in combination with extracellular matrix coatings for bladder tissue engineering with primary and pluripotent cells. PLoS One 2013;8:e56237.

15 Horst M, Madduri S, Milleret V, Sulser T, Gobet R, Eberli D: A bilayered hybrid microfibrous PLGA acellular matrix scaffold for hollow organ tissue engineering. Biomaterials 2013;34:1537-1545.

16 He H, Wu X, Wang Y, Zhu C, Tong X, Yang M, Yang L, Huang W, Wu F, Zong H, Li H, Liu Z: Preclinical animal study and human clinical trial data of co-electrospun poly(L-lactide-co-caprolactone) and fibrinogen mesh for anterior pelvic floor reconstruction. Int J Nanomed 2016;1:389-397.
Ohishi T, Koga F, Migita T: Bladder cancer stem-like cells: their origin and therapeutic perspectives. Int $\mathrm{J}$ Mol Sci 2015;17:43.

18 Dozmorov M, Kropp B, Hurst R: Differentially expressed gene networks in cultured smooth muscle cells from normal and neuropathic bladder. J Smooth 2007; 43:55-72.

19 Vaegler M, Lenis AT, Daum L, Amend B, Stenzl A, Toomey P, Renninger M, Damaser MS, Sievert KD: Stem cell therapy for voiding and erectile dysfunction. Nat Rev Urol 2012;9:435-447.

20 Wagers AJ, Weissman IL: Plasticity of adult stem cells. Cell 2004;116:639-648.

21 Burlacu A, Grigorescu G, Rosca A-M, Preda MB, Simionescu M: Factors secreted by mesenchymal stem cells and endothelial progenitor cells have complementary effects on angiogenesis in vitro. Stem Cells Dev 2013;22:643-653.

22 Baraniak PR, McDevitt TC: Stem cell paracrine actions and tissue regeneration. Regen Med 2010;5:121-143.

23 Wada N, Gronthos S, Bartold PM: Immunomodulatory effects of stem cells. Periodontol 2000 2013;63: 198-216.

24 Wang Y, Chen X, Cao W, Shi Y: Plasticity of mesenchymal stem cells in immunomodulation: pathological and therapeutic implications. Nat Immunol 2014;15: 1009-1016.

25 Takeda K, Sowa Y, Nishino K, Itoh K, Fushiki S: Adipose-derived stem cells promote proliferation, migration, and tube formation of lymphatic endothelial cells in vitro by secreting lymphangiogenic factors. Ann Plast Surg 2015;74:728-736.

26 Gomes ME, Holtorf HL, Reis RL, Mikos AG: Influence of the porosity of starch-based fiber mesh scaffolds on the proliferation and osteogenic differentiation of bone marrow stromal cells cultured in a flow perfusion bioreactor. Tissue Eng 2006;12:801-809.

27 Baker SC, Rohman G, Southgate J, Cameron NR: The relationship between the mechanical properties and cell behaviour on PLGA and PCL scaffolds for bladder tissue engineering. Biomaterials 2009;30:1321-1328.

28 Horst M, Milleret V, Nötzli S, Madduri S, Sulser T, Gobet R, Eberli D.: Increased porosity of electrospun hybrid scaffolds improved bladder tissue regeneration. J Biomed Mater Res A 2014;102:2116-2124.

29 Jiang X, Lin H, Jiang D, Xu G, Fang X, He L, Xu M, Tang B, Wang Z, Cui D, Chen F, Geng H: Co-delivery of VEGF and bFGF via a PLGA nanoparticle-modified BAM for effective contracture inhibition of regenerated bladder tissue in rabbits. Sci Rep 2016;6:1-12.

30 Jiang X, Xiong Q, Xu G, Lin H, Fang X, Cui D, Xu M, Chen F, Geng H: VEGF-loaded nanoparticle-modified BAMAs enhance angiogenesis and inhibit graft shrinkage in tissue-engineered bladder. Ann Biomed Eng 2015;43:2577-2586.

31 Uchida N, Sivaraman S, Amoroso NJ, Wagner WR, Nishiguchi A, Matsusaki M, Akashi M, Nagatomi J: Nanometer-sized extracellular matrix coating on polymer-based scaffold for tissue engineering applications. J Biomed Mater Res - Part A 2016;104:94-103.

32 Bouhout S, Rousseau A, Chabaud S, Morissette A: Potential of different tissue engineering strategies in the bladder reconstruction; in Andrades JA (ed): Regenerative Medicine and Tissue Engineering. Rijeka, Intech, 2013, pp 573-597. www.intechopen.com/books/regenerative-medicine-and-tissue-engineering/potential-ofdifferent-tissue-engineering-strategies-in-the-bladderreconstruction (last accessed July 26, 2016).

33 Ochodnicky P, Cruz CD, Yoshimura N, Cruz F: Neurotrophins as regulators of urinary bladder function. Nat Rev Urol 2012;9:628-637.
4 Chai TC, Russo A, Yu S, Lu M: Mucosal signaling in the bladder. Auton Neurosci Basic Clin 2015; doi: 10.1016/j.autneu.2015.08.009.

35 Krstic RV: Human Microscopic Anatomy: An Atlas for Students of Medicine and Biology. Heidelberg, Springer, 2013.

36 Miftahof RN, Nam HG: Biomechanics of the Human Urinary Bladder. Heidelberg, Springer, 2013, pp 163172

37 Apodaca G, Balestreire E, Birder LA: The uroepithelial-associated sensory web. Kidney Int 2007;72:10571064.

38 Hicks M: The mammalian urinary bladder: an accomodating organ. Biol Rev 1975;50:215-246.

39 Hurst RE, Rhodes SW, Adamson PB, Parsons CL, Roy JB: Functional and structural characteristics of the glycosaminoglycans of the bladder luminal surface. J Urol 1987; 138:433-437.

40 Kurzrock E a, Lieu DK, Degraffenried LA, Chan CW, Isseroff RR: Label-retaining cells of the bladder: candidate urothelial stem cells. Am J Physiol Ren Physiol 2008;294:F1415-1421.

41 Shin K, Lee J, Guo N, Kim J, Lim A, Qu L, Mysorekar IU, Beachy PA: Hedgehog/Wnt feedback supports proliferation of epithelial stem cells in bladder. Nature 2011;472:110-114.

42 Anumanthan G, Makari JH, Honea L, Thomas IC, Wills ML, Bhowmick N, Adams, Mark C, Hayward SW, Matusik RJ, Brock JW, Pope JC: Directed differentiation of bone marrow derived mesenchymal stem cells into bladder urothelium. J Urol 2008;180:17781783.

43 Zhang M, Peng Y, Zhou Z, Zhou J, Wang Z, Lu M: Differentiation of human adipose-derived stem cells cocultured with urothelium cell line toward a urothelium-like phenotype in a nude murine model. Urology 2013;81:465.e15-465.e22.

44 Bharadwaj S, Liu G, Shi Y, Wu R, Yang B, He T, Fan Y, Lu X, Zhou X, Liu H, Atala A, Rohozinski J, Zhang Y: Multipotential differentiation of human urine-derived stem cells: Potential for therapeutic applications in urology. Stem Cells 2013;31:1840-1856.

45 Long T, Wu R, Lu X, Deng J, Qin D, Zhang Y: Urinederived stem cells for tissue repair in the genitourinary system. J Stem Cell Res Ther 2015;5:317. www.omicsonline.org/open-access/urinederived-stem-cells-for-tissue-repair-in-the-genitourinary-system-2157-76331000317.php?aid=64119 (last accessed July 26, 2016).

46 Wu R, Liu G, Fan Y, Rohozinski J, Lu X, Rodriguez G, Farney A, Atala A, Zhang Y: Human urine-derived stem cells originate from parietal stem cells. J Urol 2013;189:e103.

47 Lavelle J, Meyers S, Ramage R, Bastacky S, Doty D, Apodaca G, Zedel ML: Bladder permeability barrier: recovery from selective injury of surface epithelial cells. Am J Physiol Ren Physiol 2002;283:F242-253.

48 Birder L, Andersson K-E: Urothelial signaling. Physiol Rev 2013;93:653-680.

49 Andersson K, McCloskey K: Lamina propria: the functional center of the bladder? Neurourol Urodyn 2014; 16:9-16.

50 Aitken KJ, Bägli DJ: The bladder extracellular matrix. Part I: architecture, development and disease. Nat Rev Urol 2009;6:596-611.

51 Chun SY, Lim GJ, Kwon TG, Kwak EK, Kim BW, Atala A, Yoo J: Identification and characterization of bioactive factors in bladder submucosa matrix. Biomaterials 2007;28:4251-4256.

52 Soler R, Fuellhase C, Andersson KE, Yoo JJ: The effect of lamina propria cells on the growth of urothelial and smooth muscle cells. J Urol 2009;181(suppl):78. 
53 de Groat WC, Yoshimura N: Afferent nerve regulation of bladder function in health and disease; in Rosenthal W (ed): Handbook of Experimental Pharmacology. Heidelberg, Springer, 2009, pp 91-138.

54 Ma F, Higashira H, Ukai Y, Hanai T, Kiwamoto H, Park YC, Kurita T: A new enzymic method for the isolation and culture of human bladder body smooth muscle cells. Neurourol Urodyn 2002;21:71-79.

55 Monji N, Stebbins MR, McCoy DW, Kuo JS: Isolation of the outer membrane components of Bordetella pertussis which enhance the immunogenicity of Haemophilus influenzae type b capsular polysaccharide polyribosyl ribitol phosphate. Infect Immun 1986;51:865-871.

56 Huber A, Badylak SF: Phenotypic changes in cultured smooth muscle cells: limitation or opportunity for tissue engineering of hollow organs? J Tissue Eng Regen Med 2012;6:505-511.

57 Lin HK, Cowan R, Moore P, Zhang Y, Yang Q, Peterson JA Jr, Tomasek JJ, Kropp BP, Cheng EY: Characterization of neuropathic bladder smooth muscle cells in culture. J Urol 2004;171:1348-1352.

58 Sterodimas A, de Faria J, Nicaretta B, Pitanguy I: Tissue engineering with adipose-derived stem cells (ADSCs): current and future applications. J Plast Reconstr Aesthet Surg 2010;63:1886-1892.

59 Ahn HH, Lee JYH, Kim KS, Lee JYH, Kim MS, Khang G, Lee IW, Lee HB: Polyethyleneimine-mediated gene delivery into human adipose derived stem cells. Biomaterials 2008;29:2415-2422.

60 Yang L, Geng Z, Nickel T, Johnson C, Gao L, Dutton J, Hou C, Zhang J: Differentiation of human inducedpluripotent stem cells into smooth-muscle cells: two novel protocols. PLoS One 2016;11:e0147155.

61 Jack GS, Zhang R, Lee M, Xu Y, Wu BM, Rodriguez $\mathrm{LV}$ : urinary bladder smooth muscle engineered from adipose stem cells and a three dimensional synthetic composite. Biomaterials 2009;30:3259-3270.

62 Zhang Y, McNeill E, Tian H, Soker S, Andersson KE, Yoo JJ, Atala A: Urine derived cells are a potential source for urological tissue reconstruction. J Urol 2008;180:2226-2233.

63 Bodin A, Bharadwaj S, Wu S, Gatenholm P, Atala A, Zhang Y: Tissue-engineered conduit using urinederived stem cells seeded bacterial cellulose polymer in urinary reconstruction and diversion. Biomaterials 2010;31:8889-8901.

64 Lang R, Liu G, Shi Y, Bharadwaj S, Leng X, Zhou X, Liu H, Atala A, Zhang Y: Self-renewal and differentiation capacity of urine-derived stem cells after urine preservation for 24 hours. PLoS One 2013;8:e53980.

65 Gargett CE, Schwab KE, Zillwood RM, Nguyen HP, $\mathrm{Wu} \mathrm{D}$ : Isolation and culture of epithelial progenitors and mesenchymal stem cells from human endometrium. Biol Reprod 2009;80:1136-1145.

66 Ulrich D, Muralitharan R, Gargett CE: Toward the use of endometrial and menstrual blood mesenchymal stem cells for cell-based therapies. Expert Opin Biol Ther 2013;13:1387-1400.

67 Song B, Jiang W, Alraies A, Liu Q, Gudla V, Oni J, Wei X, Ni L, Agarwal M: Bladder smooth muscle cells differentiation from dental pulp stem cells: future potential for bladder tissue engineering. Stem Cells Int 2016; 2016:1-11.

68 Hirose Y, Yamamoto T, Nakashima M, Funahashi Y, Yamaguchi M, Kawabata S, Gotoh M: Injection of dental pulp stem cells promotes healing of damaged bladder tissue in a rat model of chemically induced cystitis. Cell Transplant 2016;25:425-436.

69 Salemi S, Tremp M, Plock JA, Andersson K-EE, Gobet R, Sulser T, Eberli D: Differentiated adipose-derived stem cells for bladder bioengineering. Scand J Urol 2015;49:407-414.
70 Wang C, Yin S, Cen L, Liu Q, Liu W, Cao Y, Cui L: Differentiation of adipose-derived stem cells into contractile smooth muscle cells induced by transforming growth factor-betal and bone morphogenetic protein-4. Tissue Eng Part A 2010;16:1201-1213.

71 Tremp M, Salemi S, Largo R, Andersson KE, Plock JA, Aboushwareb T, Sulser T, Eberli D: Adipose-derived stem cells (ADSCs) and muscle precursor cells (MPCs) for the treatment of bladder voiding dysfunction. World J Urol 2014;32:1241-1248.

72 Zhu WD, Xu YM, Feng C, Fu Q, Song LJ, Cui L: Bladder reconstruction with adipose-derived stem cellseeded bladder acellular matrix grafts improve morphology composition. World J Urol 2010;28:493-498.

73 Zhe Z, Jun D, Yang Z, Mingxi X, Ke Z, Ming Z, Zhong W, Mujun L: Bladder acellular matrix grafts seeded with adipose-derived stem cells and incubated intraperitoneally promote the regeneration of bladder smooth muscle and nerve in a rat model of bladder augmentation. Stem Cells Dev 2016;25:405-414.

74 Lee JHN, Chun SY, Lee HJ, Jang YJ, Choi SH, Kim DH, Oh SH, Song PH, Lee JHN, Kim JK, Kwong TG: Human urine-derived stem cells seeded surface modified composite scaffold grafts for bladder reconstruction in a rat model. J Korean Med Sci 2015;30:1754-1763.

75 Qin D, Long T, Deng J, Zhang Y: Urine-derived stem cells for potential use in bladder repair. Stem Cell Res Ther 2014;5:69.

76 Schwab KE, Gargett CE: Co-expression of two perivascular cell markers isolates mesenchymal stem-like cells from human endometrium. Hum Reprod 2007;22: 2903-2911.

77 Kanematsu A, Yamamoto S, Iwai-Kanai E, Kanatani I, Imamura M, Adam RM, Tabata Y, Ogawa O: Induction of smooth muscle cell-like phenotype in marrowderived cells among regenerating urinary bladder smooth muscle cells. Am J Pathol 2005; 166:565-573.

78 Sharma AK, Fuller NJ, Sullivan RR, Fulton N, Hota P V, Harrington DA, Villano J, Hagerty JA, Cheng EY: Defined populations of bone marrow derived mesenchymal stem and endothelial progenitor cells for bladder regeneration. J Urol 2009;182:1898-1905.

79 Sharma AK, Hota P V., Matoka DJ, Fuller NJ, Jandali D, Thaker H, Ameer GA, Cheng EY: Urinary bladder smooth muscle regeneration utilizing bone marrow derived mesenchymal stem cell seeded elastomeric poly(1,8-octanediol-co-citrate) based thin films. Biomaterials 2010;31:6207-6217.

80 Coutu DL, Mahfouz W, Loutochin O, Galipeau J, Cor$\cos \mathrm{J}$ : Tissue engineering of rat bladder using marrowderived mesenchymal stem cells and bladder acellular matrix. PLoS One 2014;9:e111966.

81 Chung SY, Krivorov NP, Rausei V, Thomas L, Frantzen M, Landsittel D, Kang YM, Chon CH, Ng CS, Fuchs GJ: Bladder reconstitution with bone marrow derived stem cells seeded on small intestinal submucosa improves morphological and molecular composition. J Urol 2005;174:353-359.

82 Zhang Y, Lin HK, Frimberger D, Epstein RB, Kropp BP: Growth of bone marrow stromal cells on small intestinal submucosa: an alternative cell source for tissue engineered bladder. BJU Int 2005;96:1120-1125.

83 Yuan H, Zhuang Y, Xiong J, Zhi W, Liu L, Wei Q, Hang P: Human umbilical mesenchymal stem cellsseeded bladder acellular matrix grafts for reconstruction of bladder defects in a canine model. PLoS One 2013;8:e80959.

84 Blank RS, Swartz EA, Thompson MM, Olson EN, Owens GK: A retinoic acid-induced clonal cell line derived from multipotential P19 embryonal carcinoma cells expresses smooth muscle characteristics. Circ Res 1995;76:742-749.
85 Drab M, Haller H, Bychkov R, Erdmann B, Lindschau C, Haase H, Morano I, Luft FC, Wobus AM: From totipotent embryonic stem cells to spontaneously contracting smooth muscle cells: a retinoic acid and dbcAMP in vitro differentiation model. FASEB J 1997;11: 905-915.

86 Huang H, Zhao X, Chen L, Xu C, Yao X, Lu Y, Dai L, Zhang M: Differentiation of human embryonic stem cells into smooth muscle cells in adherent monolayer culture. Biochem Biophys Res Commun 2006;351: 321-327.

87 Xie CQ, Zhang J, Villacorta L, Cui T, Huang H, Chen YE: A highly efficient method to differentiate smooth muscle cells from human embryonic stem cells. Arter Thromb Vasc Biol 2007;27:e311-312.

88 Lakshmanan Y, Frimberger D, Gearhart JPD, Gearhart JPD: Human embryoid body-derived stem cells in coculture with bladder smooth muscle and urothelium. Urology 2005;65:821-826.

89 Frimberger D, Morales N, Shamblott M, Gearhart JPD, Gearhart JPD, Lakshmanan Y: Human embryoid body-derived stem cells in bladder regeneration using rodent model. Urology 2005;65:827-832.

90 Fernandez CE, Achneck HE, Reichert WM, Truskey GA: Biological and engineering design considerations for vascular tissue engineered blood vessels (TEBVs). Curr Opin Chem Eng 2014;3:83-90

91 Marchand M, Anderson EK, Phadnis SM, Longaker MT, Cooke JP, Chen B, Reijo Pera RA: Concurrent generation of functional smooth muscle and endothelial cells via a vascular progenitor. Stem Cells Transl Med 2014;3:91-97.

92 Patel ZS, Mikos AG: Angiogenesis with biomaterialbased drug- and cell-delivery systems. J Biomater Sci Polym Ed 2004;15:701-726.

93 Benz S, Nötzli S, Siegel JS, Eberli D, Jessen HJ: Controlled oxygen release from pyridone endoperoxides promotes cell survival under anoxic conditions. J Med Chem 2013;56:10171-10182

94 Lee TT, García JR, Paez JI, Singh A, Phelps EA, Weis S, Shafiq Z, Sherakan A, Campo A, Garcìa AJ: Light-triggered in vivo activation of adhesive peptides regulates cell adhesion, inflammation and vascularization of biomaterials. Nat Mater 2015;14:352-360.

95 Klar AS, Güven S, Biedermann T, Luginbühl J, Böttcher-Haberzeth S, Meuli-Simmen C, Meuli Martin I, Scherberich A, Reichman E: Tissue-engineered dermo-epidermal skin grafts prevascularized with adipose-derived cells. Biomaterials 2014;35:5065-5078.

96 Laschke MW, Menger MD: Prevascularization in tissue engineering: current concepts and future directions. Biotechnol Adv 2015;34:112-121.

97 Salgado AJ, Reis RL, Sousa NJ, Gimble JM: Adipose tissue derived stem cells secretome: soluble factors and their roles in regenerative medicine. Curr Stem Cell Res Ther 2010;5:103-110.

98 Anderson JD, Johansson HJ, Graham CS, Vesterlund M, Pham MT, Bramlett CS, Montgomery EN, Mellema MS, Bardini RL, Contreras Z, Hoon M, Bauer G, Fink KD, Fury B, Hendrix KJ, Chedin F, El-Andaloussi S, Hwang B, Mulligan MS, Lehtiö J, Nolta JA: Comprehensive proteomic analysis of mesenchymal stem cell exosomes reveals modulation of angiogenesis via NFkB signaling. Stem Cells 2016; DOI: 10.1002/stem.2298.

99 Tran C, Damaser MS: Stem cells as drug delivery methods: application of stem cell secretome for regeneration. Adv Drug Deliv Rev 2015;82:1-11.

100 Caplan AI: Adult mesenchymal stem cells: when, where, and how. Stem Cells Int 2015;2015:628767.

101 Terlizzi V, Hammes H, Harmsen M: Adipose-derived stromal cells contribute to microvascular stabilization in diabetic proliferative retinopathy: to be or not to be? Diabetol Stoffwechsel 2015;10:P69. 
102 Grainger SJ, Carrion B, Ceccarelli J, Putnam AJ: Stromal cell identity influences the in vivo functionality of engineered capillary networks formed by co-delivery of endothelial cells and stromal cells. Tissue Eng Part A 2013;19:1209-1222.

103 Hannick J, Diaz E, Snow-Lisy D, Bury M, Fuller N Ahmad N, Sharma A: Mp19-11 Wnt-5a overexpressing mesenchymal stem cells enhance bladder muscle, vessel, nerve, and urothelium regeneration in a murine model of bladder augmentation. J Urol 2015;193:e219.

104 Wankhade UD, Shen M, Kolhe R, Fulzele S: Advances in adipose-derived stem cells isolation, characterization, and application in regenerative tissue engineering. Stem Cells Int 2016;2016:3206807.

105 Drake MJ, Gardner BP, Brading AF: Innervation of the detrusor muscle bundle in neurogenic detrusor overactivity. BJU Int 2003;91:702-710.

106 Hu J, Tian L, Prabhakaran M, Ding X, Ramakrishna S: Fabrication of nerve growth factor encapsulated aligned poly( $\varepsilon$-caprolactone) nanofibers and their assessment as a potential neural tissue engineering scaffold. Polymers (Basel) 2016;8:54.

107 Cui W, Zhou Y, Chang J: Electrospun nanofibrous materials for tissue engineering and drug delivery. Sci Technol Adv Mater 2010;11:014108.

108 Belanger K, Dinis TM, Taourirt S, Vidal G, Kaplan DL, Egles C: Recent strategies in tissue engineering for guided peripheral nerve regeneration. Macromol Biosci 2016;16:472-481.

109 Hardy J, Cornelison R, Sukhavasi R, Saballos R, Vu P, Kaplan D, Schmidt C: Electroactive tissue scaffolds with aligned pores as instructive platforms for biomimetic tissue engineering. Bioengineering 2015;2:15-34.

110 Wu Y, Wang L, Guo B, Shao Y, Ma PX: Electroactive biodegradable polyurethane significantly enhanced Schwann cells myelin gene expression and neurotrophin secretion for peripheral nerve tissue engineering. Biomaterials 2016;87:18-31.
111 Wang Y, Kong Y, Zhao Y, Feng Q, Wu Y, Tang X, Gu $\mathrm{X}$, Yang Y: Electrospun, reinforcing network-containing, silk fibroin-based nerve guidance conduits for peripheral nerve repair. J Biomater Tissue Eng 2016;6: 53-60.

112 Zuidema JM, Provenza C, Caliendo T, Dutz S, Gilbert RJ: Magnetic NGF-releasing PLLA/iron oxide nanoparticles direct extending neurites and preferentially guide neurites along aligned electrospun microfibers. ACS Chem Neurosci 2015;6:1781-1788.

113 Chang Y-J, Hsu C-M, Lin C-H, Lu MS-C, Chen L: Electrical stimulation promotes nerve growth factorinduced neurite outgrowth and signaling. Biochim Biophys Acta 2013;1830:4130-4136.

114 StÖlting MNL, Arnold AS, Haralampieva D, Handschin C, Sulser T, Eberli D: Magnetic stimulation supports muscle and nerve regeneration after trauma in mice. Muscle Nerve 2016;53:598-607.

115 Paschos NK, Brown WE, Eswaramoorthy R, Hu JC, Athanasiou KA: Advances in tissue engineering through stem cell-based co-culture. J Tissue Eng Regen Med 2015;9:488-503.

116 Kingham PJ, Kalbermatten DF, Mahay D, Armstrong SJ, Wiberg M, Terenghi G: Adipose-derived stem cells differentiate into a Schwann cell phenotype and promote neurite outgrowth in vitro. Exp Neurol 2007;207: 267-274.

117 Kushnerev E, Shawcross SG, Hillarby MC, Yates JM: High-plasticity mesenchymal stem cells isolated from adult-retained primary teeth and autogenous adult tooth pulp-A potential source for regenerative therapies? Arch Oral Biol 2016;62:43-48.

118 Wakao S, Matsuse D, Dezawa M: Mesenchymal stem cells as a source of Schwann cells: their anticipated use in peripheral nerve regeneration. Cells Tissues Organs 2014;200:31-41.
119 Jaatinen L, Salemi S, Miettinen S, Hyttinen J, Eberli D: The combination of electric current and copper promotes neuronal differentiation of adipose-derived stem cells. Ann Biomed Eng 2015;43:1014-1023.

120 Sowa Y, Kishida T, Imura T, Numajiri T, Nishino K, Tabata Y, Mazda O: Adipose-derived stem cells promote peripheral nerve regeneration in vivo without differentiation into Schwann-like lineage. Plast Reconstr Surg 2016;137:318e-330e.

121 Bohne AW, Urwiller KL: Experience with urinary bladder regeneration. J Urol 1957;77:725-732.

122 Adamowicz J, Pokrywczynska M, Drewa T: Conditioned medium derived from mesenchymal stem cells culture as a intravesical therapy for cystitis interstitials. Med Hypotheses 2014;82:670-673.

123 Portilla Sanchez R, Blanco FL, Santamarina A, Casals Roa J, Mata J, Kaufman A: Vesical regeneration in the human after total cystectomy and implantation of a plastic mould. Br J Urol 1958;30:180-188.

124 Tsulukidze A, Murvanidze D, Dvali R, Ivashchenko G: Formation of a bladder by a plastic shell after total cystectomy. Br J Urol 1964;36:102-105.

125 Tsuji I, Kuroda K, Fujieda J, Shiraishi Y, Kunishima K Clinical experiences of bladder reconstruction using preserved bladder and gelatin sponge bladder in the case of bladder cancer. J Urol 1967;98:91-92.

126 Orikasa S, Tsuji I: Enlargement of contracted bladder by use of gelatin sponge bladder. J Urol 1970;104:107110.

127 Taguchi H, Ishizuka E, Saito K: Cystoplasty by regeneration of the bladder. J Urol 1977;118:752-756.

128 Tsuji I, Kuroda K, Fujieda J, Shiraishi Y, Kassai T, Shida H: A clinical and experimental study on cystoplasty not using the intestine. J Urol 1963;89:214-225.

129 Atala A, Bauer SB, Soker S, Yoo JJ, Retik AB: Tissueengineered autologous bladders for patients needing cystoplasty. Lancet 2006;367:1241-1246. 